\title{
研究報文
}

\section{有機質肥料と床土原土との混和時期が 水稲苗の生育に及ぼす影響}

\author{
朝妻英治* ・高橋行継** ・平井英明** \\ *東京農工大学大学院連合農学研究科 \\ ** 宇都宮大学農学部
}

\begin{abstract}
Mixing Organic Fertilizer with Nursery Soil : Effect of Fallow Duration on Growth of Paddy Rice Seedlings
\end{abstract}

\author{
Eiji Asatsuma*, Yukitsugu Takahashi** and Hideaki Hirai** \\ * Graduate School of Agriculture, Tokyo University of Agriculture and Technology, Japan \\ ${ }^{* *}$ Faculty of Agriculture, Utsunomiya University, Japan
}

\section{1. 緒言}

水稲有機栽培においては，各都道府県から挙げ られた諸問題の一つとして，水稲育苗対策に係る 問題がある（日本土㙵協会 2012a）。

有機質資材の使用に関しては，それらの特異的 な窒素無機化パターンにより肥効調節が困難であ り，施用量や施用時期により水稲苗に障害を引き 起こすなどの影響を及ぼすこと（進藤ら 2006）, また有機質資材を窒素源として利用するとムレ苗 が起こりやすい（日本土壌協会 2012b）といった 栽培上の問題点が報告されている。ムレ苗とは 2 3 葉期に苗が急激に枯死する症状であり, 岡山 （1987）は床土 $\mathrm{pH}$ の上昇によりピシウム属菌が 繁殖し, 更に苗床の低温条件が菌に侵され易い環 境を作るとしており, 床土 $\mathrm{pH}$ の上昇と低温条件 の両要因がムレ苗の発生を助長するとしている. 有機物の混和により床土の $\mathrm{pH}$ が上昇することが

平成 25 年 3 月 27 日受付

平成 26 年 1 月 11 日受理

Corresponding author

朝妻英治 Eiji Asatsuma

テ321-0923栃木県宇都宮市下栗町 2764-4 D’フレアタウ ン長宮 III 201

D' Fureatown Ngamiya III 201, 2764-4 Shimogurimati. Utsunomiya. 321-0923. Tochigi Japan.

E-mail : eiji0712@miya.jm.utsunomiya-u.ac.jp
知られており（金ら 2007），有機育苗においては ムレ苗発生の助長要因の一つであると考えられ る. 日本土壤協会 $(2012 b)$ は水稲有機育苗にお けるムレ苗の抑制技術としてプール育苗方法を奖 励しており, 米倉・大下 $(2000)$ はプール育苗方法 において，事前に有機質肥料と床土原土を混和す ることで苗立枯症状も抑制できると報告してい る。また, 浦野ら（2011）は, 有機育苗に用いる有 機質肥料は菜種油粕および魚粕（以下魚粉と記述 する）が適しており，その施用量は窒素成分でそ れぞれ $1 \mathrm{~g}$ ずつ, 箱当り $2 \mathrm{~g}$ が適当と報告してお り, この施用量でのプール育苗方式により苗立枯 症状, ムレ苗の発生は無く, かつ健苗が得られる と報告している.

水稲有機栽培には, 緩効的な肥効発現系, 雑草・ 病害虫防除等の観点から，移植直後に良好な初期 生育が期待される中苗以上の苗の使用が望ましい （江上ら 2009, 菊地・鈴木 2009, 鈴木 - 菊地 2009) と考えられるが，有機育苗における中苗育成に関 して詳細に報告された例が少なく, 浦野ら (2012) の報告に抢いても混和時期に関しては明らかにさ れていない.

以上の背景から本研究では, 有機質肥料を利用 した培土を供試し，有機中苗として本田機械移植 に対応した生育，品質を有する水稲苗の生産技術 の確立に資することを目的として，プール育苗条 
件下の中苗育成における魚粉, 菜種油粕と床土原 土との混和時期が水稲苗の生育, 苗質に及ぼす影 響について, 2011 年, 2012 年の 2 か年にわたり検 討したので報告する.

\section{2. 材料および方法}

1）栽培管理の概要と試験区の設定

試験は 2011 年, 2012 年の 2 か年, 宇都宮大学 農学部附属農場内（以下, 附属農場と略称）のガ ラス温室，およびハウス内で実施した。供試品種 はコシヒカリを用いた。

種子予措並びに播種作業は, 附属農場慣行法に 従った. 播種は, 2011 年では 4 月 21 日，2012 年 では 4 月 24 日に行った。両年共に播種量は乾籾 換算で $100 \mathrm{~g} /$ 箱（育苗箱の大きさは $60 \mathrm{~cm} \times 30$ $\mathrm{cm})$ とし, 床土は, 宇都宮大学農学部附属農場内 の森林下の表層土 (黒ボク土) (以下, 山土と略称) に，有機質肥料を混和したものを育苗箱（丸三産 業株式会社製ニューライン) あたり $2.15 \mathrm{~L}$, 覆土と して有機質肥料を混和していない山土 $1 \mathrm{~L}$ を充填 した，有機質肥料として魚粉（カネミ倉庫株式会 社製), 菜種油粕（Jオイルパーム株式会社製）を 使用した。それぞれの肥料保証成分量 $\left(\mathrm{N}: \mathrm{P}_{2} \mathrm{O}_{5}\right.$ : $\left.\mathrm{K}_{2} \mathrm{O}\right)$ は, 菜種油粕 $5.3: 2.0: 1.0$, 魚粉 $7.0: 7.0$ : 0.5 であり, $\mathrm{C} / \mathrm{N}$ 比は菜種油粕 6.9 , 魚粉は 4.6 で あった．箱当たりの有機質肥料の施用について は, 浦野ら（2011）に従った. すなわち, 両有機質 肥料を窒素成分比 $1: 1$ で混和したものを供試し, その施肥量は窒素成分で $2 \mathrm{~g} /$ 箱とし, 供試した有 機質肥料と山土を混和する時期を異にした試験区 を設定した，播種 4 週間前, 2 週間前, 1 週間前に 有機質肥料を山土と混和し暗所保存した培土と, 播種日当日に有機質肥料を山土と混和した培土を 使用し，育苗試験を実施した。それぞれ $4 \mathrm{~W}$ 区, 2W 区，1W 区，0W 区として，計 4 試験区を設け た. 育苗試験は 3 反復で行った。

本試験においては, 播種後の出芽作業を 2011 年はガラス温室内, 2012 年はハウス内において平 置き出芽法（高橋ら 1993, 高橋ら 2004）によって 実施した。その際にシルバーラブ（東鑵興産株式 会社製）を被覆資材として使用した。 2011 年, 2012 年共に出芽長が概ね $1 \mathrm{~cm}$ に達した時点で被 覆資材を除去し, その後もガラス温室内, ハウス 内管理とし, 播種日から起算して 10 日目以降は ハウス内でのビニールプール育苗（以下，プール
育苗と略称)（高橋ら 2004, 高橋・吉田 2006）に移 行した。プール育苗時の水管理は，基本的に常時 湛水条件（水深 $2 \sim 3 \mathrm{~cm}$ ) とした. 育苗期間は, 播種日から起算して 30 日間とした（2011 年は 4 月 21 日から 5 月 21 日, 2012 年は 4 月 24 日から 5 月 24 日).

\section{2）調查方法}

苗の生育状況を比較するために, 草丈, 葉齢, 第 1 葉葉鞘高, 葉色值, 地上部乾物重, 生育むら, 地下部障害, 立枯症状および苗窒素含有率を調查 した，草丈および葉噛は，育苗箱の周縁部を除い た場所から任意に 20 個体を選択し，播種後 16 日 目，30日目（育苗完了日）に測定した。なお，第 1 葉は不完全葉を除いた葉位とした，第 1 葉葉鞘 高は同じく育苗箱の周縁部を除いた場所から任意 に 20 個体を選択し, 播種後 30 日目（育苗完了日） に測定した。葉色は, 2011 年では葉緑素計（コニ カミノルタセンシング株式会社製：SPAD-502) で測定した数值（SPAD 值）を, 2012 年では葉色 板を用いた 1 6 の段階評価を, 葉色值とし, 評価 した．育苗箱の周縁部を除いた場所から任意に 10 個体を調查し, その平均值を箱全体の葉色値と した。測定部位は各々の調查時点における最上位 展開葉のほほ中央部とした。地上部乾物重は播種 後 30 日目（育苗完了日）に育苗箱の周縁部を除い た場所から任意に 100 個体を採取し, $80^{\circ} \mathrm{C}$ の通風 乾燥器で 48 時間乾燥した後, 重量を測定した. 生育むら, 苗立枯症状は浦野ら (2011) に従い, そ れぞれ育苗完了時, 苗出芽時に育苗箱内の観察に よる 1〜 5段階の相対評価として調査した. 地下 部障害については形成されたマット苗根部の観察 による 1〜 5段階の相対評価として調查した。 苗 の窒素含有率は, 乾物重測定に使用した $80^{\circ} \mathrm{C}$ 通風 乾燥した 100 個体を粉砕機（HEIKO 社製 SAMPLE MILL TI-100) で微粉砕し，NC アナラ イザー（住化分析センター製 SUMIGRAPH NC22F）で各試料の窒素含有率を測定して求めた. また, 求めた窒素含有率, 100 個体乾物重および 栽植密度から苗の箱当たり窒素含量を算出した。

得られた結果の統計解析は STATISTICA2000 (StatSoft,Inc) を用いて多重検定（Tukey 法）で 行った. 


\section{3. 結果}

1）有機質肥料（魚粉・菜種油粕）の床土原土との 混和時期が苗の生育に及ぼす影響

播種後 16 日目と 30 日目の苗生育を表 1 に示し た. 播種後 16 日目においては, 2011 年, 2012 年 ともに草丈では混和後の保存期間が長い試験区が 高くなる傾向を示した. 2011 年と 2012 年ともに $4 \mathrm{~W}$ 区で最大值 $(2011$ 年 $11.6 \mathrm{~cm}, 2012$ 年 $16.6 \mathrm{~cm}$ ) を示した。播種後 30 日目の育苗完了時において, 2011 年は $2 \mathrm{~W}$ 区が最高の $16.7 \mathrm{~cm}, 0 \mathrm{~W}$ 区が最低の $15.7 \mathrm{~cm}$ を示した．各試験区に有意差は認められ なかった. 2012 年では $4 \mathrm{~W}$ 区が最大の $18.6 \mathrm{~cm}$ で, $0 \mathrm{~W}$ 区が最も低い $13.7 \mathrm{~cm}$ となり, $4 \mathrm{~W}$ 区, $2 \mathrm{~W}$ 区に比べ5\%水準で有意に低い值を示した。

葉龄については，2012 年播種後 16 日目におい て $4 \mathrm{~W}$ 区が 3.3 と $0 \mathrm{~W}$ 区に比べ $5 \%$ 水準で有意に 高い值を示した，両年ともに播種後 30 日目の育 苗完了時においては各試験区に有意な差は認めら れなかった。

第 1 葉葉鞘高については草丈と同様に混和後の 保存期間が長いほど高くなる傾向にあった，4W 区は 2011 年では $3.2 \mathrm{~cm}, 2012$ 年では $4.4 \mathrm{~cm}$ と両
年ともに $1 \mathrm{~W}, 0 \mathrm{~W}$ 区に比べ $5 \%$ 水準で有意に高い 值を示した.

葉色値については 2012 年播種後 16 日目におい て $2 \mathrm{~W}$ 区が $0 \mathrm{~W}$ 区に比 $5 \%$ 水準で有意に高い值を 示したが，両年を通じて播種後 30 日後の育苗完 了時には各試験区間に有意な差は認められなかっ た.

地上部乾物重について，両年ともに $0 \mathrm{~W}$ 区が最 低值を示しており，2012 年では $4 \mathrm{~W}, 2 \mathrm{~W}$ 区に比 5\%水準で有意に低かった.

2) 有機質肥料（魚粉・菜種油粕）の床土原土との 混和時期が苗マットの形質に及ぼす影響

育苗完了時苗マットの形質を表 2 に示した，生 育むらにおいては両年ともに混和後の保存期間が 長いほど大きい值を示す傾向があり，2011 年では $4 \mathrm{~W}$ 区が他の試験区に比べ $5 \%$ 水準で有意に高く なった。

地下部障害，苗立枯症状は両年を通じて全試験 区において見られなかった。

3）有機質肥料（魚粉・菜種油粕）の床土原土との 混和時期が苗窒素含量に及ぼす影響

表 1 有機質肥料（魚粕，菜種油粕）と床土原土との混和時期が苗の生育に及ぼす影響

\begin{tabular}{|c|c|c|c|c|c|c|c|c|c|}
\hline \multirow[b]{2}{*}{ 年次 } & \multirow[b]{2}{*}{ 試験区 } & \multicolumn{3}{|c|}{ 播種後 16 日目 } & \multicolumn{5}{|c|}{ 播種後 30 日目（育苗完了日） } \\
\hline & & $\begin{array}{l}\text { 草丈 } \\
(\mathrm{cm})\end{array}$ & 葉齢 & 葉色值 & $\begin{array}{l}\text { 草丈 } \\
(\mathrm{cm})\end{array}$ & 葉齢 & $\begin{array}{c}\text { 第 } 1 \text { 葉 } \\
\text { 葉鞘高 } \\
(\mathrm{cm})\end{array}$ & 葉色值 & $\begin{array}{c}\text { 苗地上部 } \\
\text { 乾物重 } \\
(\mathrm{g} / 100 \text { 個体 })\end{array}$ \\
\hline \multirow[t]{4}{*}{2011} & 4W 区 & $11.6 \mathrm{a}$ & $2.9 \mathrm{a}$ & 23.1a & $16.3 \mathrm{a}$ & 4.1a & $3.2 \mathrm{a}$ & $24.2 \mathrm{a}$ & $1.98 \mathrm{a}$ \\
\hline & 2W 区 & $11.0 \mathrm{a}$ & $2.9 \mathrm{a}$ & $25.5 \mathrm{a}$ & $16.7 \mathrm{a}$ & 4.1a & $3.0 \mathrm{ab}$ & $25.5 \mathrm{a}$ & $1.84 \mathrm{a}$ \\
\hline & 1W 区 & $9.9 \mathrm{a}$ & $2.9 \mathrm{a}$ & $24.0 \mathrm{a}$ & $16.0 \mathrm{a}$ & 4.1a & $2.9 \mathrm{bc}$ & $25.0 \mathrm{a}$ & $1.59 \mathrm{a}$ \\
\hline & 0W 区 & $10.0 \mathrm{a}$ & $2.9 \mathrm{a}$ & $27.0 \mathrm{a}$ & $15.7 \mathrm{a}$ & $4.2 \mathrm{a}$ & $2.8 \mathrm{c}$ & $22.9 \mathrm{a}$ & $1.52 \mathrm{a}$ \\
\hline \multirow[t]{4}{*}{2012} & 4W 区 & $16.6 \mathrm{a}$ & $3.3 \mathrm{a}$ & $5.0 \mathrm{ab}$ & $18.6 \mathrm{a}$ & $4.2 \mathrm{a}$ & $4.4 \mathrm{a}$ & $2.8 \mathrm{a}$ & $2.45 \mathrm{a}$ \\
\hline & 2W 区 & $15.7 \mathrm{a}$ & $3.2 \mathrm{ab}$ & $5.8 \mathrm{a}$ & $17.6 \mathrm{a}$ & $4.2 \mathrm{a}$ & $4.2 \mathrm{a}$ & $3.2 \mathrm{a}$ & $2.50 \mathrm{a}$ \\
\hline & 1W 区 & $14.4 \mathrm{ab}$ & $3.2 \mathrm{ab}$ & $5.0 \mathrm{ab}$ & $16.2 \mathrm{ab}$ & 4.1a & $3.9 \mathrm{~b}$ & $2.7 \mathrm{a}$ & $2.41 \mathrm{ab}$ \\
\hline & 0W 区 & $12.7 \mathrm{~b}$ & $3.0 \mathrm{~b}$ & $4.0 \mathrm{~b}$ & $13.7 \mathrm{~b}$ & $4.0 \mathrm{a}$ & $3.9 \mathrm{~b}$ & $2.3 \mathrm{a}$ & $1.99 \mathrm{~b}$ \\
\hline \multicolumn{5}{|c|}{$\begin{array}{c}\text { 育苗完了時 } \\
\text { 中苗生育指標 }\end{array}$} & $14 \sim 18$ & $3.4 \sim 4.5$ & 3 & - & \\
\hline $\begin{array}{l}\text { 草丈, } \\
\text { 等の障 } \\
\text { 草丈, } \\
\text { 第一葉 } \\
\text { 葉色值 } \\
\text { 乾物重 } \\
\text { 統計分 } \\
\text { ことを } \\
\text { 一は指 } \\
\text { 中苗生 }\end{array}$ & 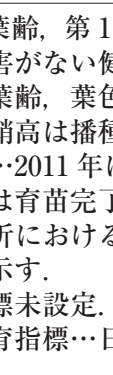 & 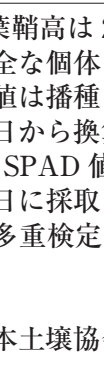 & $\begin{array}{l}\text { 個体の } \\
\text { した.). } \\
\text { から換算 } \\
\text { して } 30 \\
2012 \text { 年 } \\
\text { た } 100 \text { 供 } \\
\text { 年度毎! }\end{array}$ & $\begin{array}{l}\text { 均值. 葉 } \\
\text { して } 16 \\
\text { 後 (育南 } \\
\text { さ葉色板 } \\
\text { 体の絶乾 } \\
\text { 実施し, }\end{array}$ & $\begin{array}{l}\text { 值は } 101 \\
\text { と } 30 \text { 日 } \\
\text { 了日) } 0 \\
\text { る } 1 \sim 6 \\
\text { 態での合 } \\
\text { 一アルフ }\end{array}$ & $\begin{array}{l}\text { 本の平均佌 } \\
\text { (育苗完 } \\
\text { を示した } \\
\text { 階の育苗 } \\
\text { 直. } \\
\text { ベットは }\end{array}$ & $\begin{array}{l}\text { 但し, 調 } \\
\text { 内相対評 } \\
\text { のey 值 }\end{array}$ & $\begin{array}{l}\text { 対象は立 } \\
\text { 六した。 } \\
\text { り } 5 \% \text { 水 }\end{array}$ & 枯れ, 生育むら \\
\hline
\end{tabular}


表 2 有機質肥料 (魚粕, 菜種油粕) と床土原土と の混和時期が苗マットの形質に及ぼす影響

\begin{tabular}{ccccc}
\hline \hline 年次 & 試験区 & 生育むら & $\begin{array}{c}\text { 地下部 } \\
\text { 障害 }\end{array}$ & 立枯症状 \\
\hline 2011 & $4 \mathrm{~W} 区$ & $3.0 \mathrm{a}$ & $1.0 \mathrm{a}$ & $1.0 \mathrm{a}$ \\
& $2 \mathrm{~W}$ 区 & $2.0 \mathrm{~b}$ & $1.0 \mathrm{a}$ & $1.0 \mathrm{a}$ \\
& $1 \mathrm{~W}$ 区 & $1.7 \mathrm{bc}$ & $1.0 \mathrm{a}$ & $1.0 \mathrm{a}$ \\
& $0 \mathrm{~W}$ 区 & $1.0 \mathrm{c}$ & $1.0 \mathrm{a}$ & $1.0 \mathrm{a}$ \\
\hline 2012 & $4 \mathrm{~W}$ 区 & $2.0 \mathrm{a}$ & $1.0 \mathrm{a}$ & $1.0 \mathrm{a}$ \\
& $2 \mathrm{~W}$ 区 & $2.0 \mathrm{a}$ & $1.0 \mathrm{a}$ & $1.0 \mathrm{a}$ \\
& $1 \mathrm{~W}$ 区 & $1.0 \mathrm{a}$ & $1.0 \mathrm{a}$ & $1.0 \mathrm{a}$ \\
& $0 \mathrm{~W}$ 区 & $1.0 \mathrm{a}$ & $1.0 \mathrm{a}$ & $1.0 \mathrm{a}$ \\
\hline
\end{tabular}

生育むら, 地下部障害および立枯症状は

育苗箱内の観察による 1 5 段階評価（無〜甚）の 達観評価.

統計分析に抢ける多重検定は年度每に実施し，同一 アルファベットは Tukey 法により $5 \%$ 水準で有意 差のないことを示す.

表 3 有機質肥料（魚粕，菜種油粕）と床土原土 との混和時期が苗窒素含量に及ぼす影響

\begin{tabular}{cccc}
\hline \hline 年次 & 試験区 & $\begin{array}{c}\text { 苗窒素含有率 } \\
(\%)\end{array}$ & $\begin{array}{c}\text { 苗の箱当り } \\
\text { 窒素含量 }\left(\mathrm{g} / \text { 箱 }^{2}\right)\end{array}$ \\
\hline 2011 & $4 \mathrm{~W}$ 区 & $3.56 \mathrm{a}$ & $1.93 \mathrm{a}$ \\
& $2 \mathrm{~W}$ 区 & $3.45 \mathrm{a}$ & $1.74 \mathrm{a}$ \\
& $1 \mathrm{~W}$ 区 & $3.10 \mathrm{~b}$ & $1.49 \mathrm{a}$ \\
& $0 \mathrm{~W}$ 区 & $3.46 \mathrm{a}$ & $1.44 \mathrm{a}$ \\
\hline 2012 & $4 \mathrm{~W}$ 区 & $2.68 \mathrm{a}$ & $1.79 \mathrm{a}$ \\
& $2 \mathrm{~W}$ 区 & $2.78 \mathrm{a}$ & $1.90 \mathrm{a}$ \\
& $1 \mathrm{~W}$ 区 & $2.27 \mathrm{ab}$ & $1.63 \mathrm{ab}$ \\
& 0W 区 & $1.91 \mathrm{~b}$ & $1.04 \mathrm{~b}$
\end{tabular}

栽植密度は 2012 年度と同じとして算出.

統計分析における多重検定は年度毎に実施し，同一 アルファベットは Tukey 法により $5 \%$ 水準で有意 差のないことを示す.

育苗完了時苗の窒素含量を表 3 に示した。 窒素 含有率においては, 2011 年で $1 \mathrm{~W}$ 区が他の 3 試験 区に比べ $5 \%$ 水準で有意に低く, $3.10 \%$ で最低で あった４W 区が最高の $3.56 \%$ 示したが， $2 \mathrm{~W}$ 区，0W 区とほぼ同等であった。 2012 年において は混和時期が早い試験区で多い傾向が見られ, $2 \mathrm{~W}$ 区が最大の $2.78 \%$ であった。 $0 \mathrm{~W}$ 区が最も低 い $1.91 \%$ で，4W 区，2W 区に比べ5\%水準で有意 に低い值を示した。

箱当りの窒素含量については, 両年ともに混和 時期の早い $4 \mathrm{~W}, 2 \mathrm{~W}$ 区で高く, $1 \mathrm{~W}$ 区, $0 \mathrm{~W}$ 区で低 い傾向を示した. 2011 年では $4 \mathrm{~W}$ 区が最大の 1 . $93 \mathrm{~g}, 2012$ 年では $2 \mathrm{~W}$ 区が最大の $1.90 \mathrm{~g}$ を示した.
両年ともに $0 \mathrm{~W}$ 区が最低でそれぞれ $1.44 \mathrm{~g}, 1.04 \mathrm{~g}$ であった。 2011 年では各試験区に有意差は見ら れなかったが, 2012 年では, $0 \mathrm{~W}$ 区は $4 \mathrm{~W}$ 区, $2 \mathrm{~W}$ 区に比べ $5 \%$ 水準で有意に低い值であった.

\section{4. 考察}

4W 区について, 表 2 より 2011 年度試験におい ては他の試験区に比べ，箱全体に明らかな生育む らが確認された。 また, 2012 年度においても有意 差は認められなかったものの, 生育むらが発生し ていた，肥料の混和むらについては，同じ条件で 混和作業を行った $0 \mathrm{~W}$ 区，1W 区では生育むらが 小さかったことから，本試験においては生育むら 発生の要因ではないと考えられた。田淵ら(2011) は菜種油粕を使用し育苗すると, 種類, 施用量に よっては根の発育抑制などの障害発生が確認さ れ，ルートマットの形成が不十分で強度のないも のとなるとしており，山根（1986）によると菜種 油粕は分解過程で植物の生長に有害な有機酸など を放出するとしている，本試験ではマット強度, 地下部乾物重の調查を行っていないが, 育苗終了 時の相対評価においては地下部に障害の発生は認 められず，また苗立枯症状の発生も確認されな かったことから（表 2)，田淵ら（2011）の報告に ある根の発育抑制や米倉・大下（2000）の言う菜 種油粕の分解に伴う障害は起こらなかったと推察 された，従ってこれらも本試験においては生育む ら発生の原因ではないと考えられた。

本試験での 2011 年および 2012 年それぞれの苗 地上部の箱当り窒素含量と生育むらの関係を図 1 に示した，図 1 より $2 \mathrm{~W}, 4 \mathrm{~W}$ 区のように, 苗地上 部の箱当り窒素含量が $1.7 \mathrm{~g}$ 以上になると生育む らが多く発生する傾向を示した（図1の円内). このことから, 培土保存期間が長い程箱当り苗地 上部窒素含量が大きくなるとともに生育むらも増 える傾向にあった（表 3 ).

有機栽培に適したあるいは慣行中苗と遜色のな い苗質とされる苗生育指標に関する報告（日本土 蛮協会 $2012 b$, 菊地・鈴木 2009, 星川 1982) と本 試験区の苗生育を比較した (表 1)。全試験区にお いて苗生育量はほぼ範囲内, あるいは同程度で あった。また本試験の $0 \mathrm{~W}$ 区においては，有機物 の播種当日混和により䯚念される苗立枯症状の発 生（米倉・大下 2000）も認められなかった。 しか し, 本試験では培土保存期間が長い程苗地上部箱 


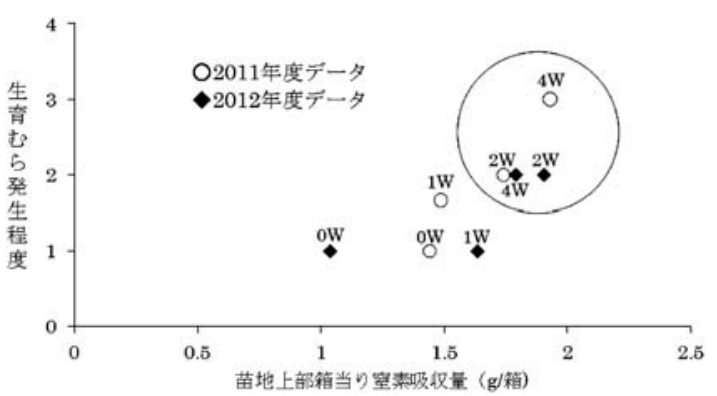

図 1 苗地上部箱当り窒素吸収量と生育むらの関係

当り窒素含量が増加し, 箱内に生育むらが発生す る傾向が認められた。機械移植の際に出芽, 生育 むらのあるマット苗は欠株や移植後の本田での生 育に影響を及ぼすことが知られており（鷲尾 1982), 疎植栽培が奨励される水稲有機栽培体系 の中にあっては, 特に欠株は問題となる。 すなわ ち, 箱全体（単一のマット）としては移植時に作 業性の悪化を引き起こし, 収量性について悪影響 をおよぼす，得に $4 \mathrm{~W}$ 区は他の試験区に比べ有意 に生育むらが相対評価 3 という高い值を示すこと があった（表 2)。このことから，播種 4 週前に魚 粉, 菜種油粕を混和した培土で育成した苗は, 機 械移植を前提とした水稲有機栽培において使用す るには課題の残るマット苗であった。

\section{摘要}

水稲有機栽培において, 健全な有機中苗生産技 術の確立に資することを目的として，プール育苗 方法, 中苗育成に抢ける魚分, 菜種油粕の床土原 土との混和時期が水稲苗におよぼす影響について 検討した. 魚粉と菜種油粕をそれぞれ窒素成分 $1: 1$ で配合したもの（箱当たり窒素成分量 $2 \mathrm{~g}$ ) と 森林下の表層土（山土）を 4 週間前, 2 週間前, 1 週間前, 播種当日に混和した培土を使用し育苗し た 4 試験区で実施した。各試験区について苗生育 および窒素含量を調查した，設定した全ての培土 で育成した苗に生育障害は認められなかったが, 一方で播種 4 週間前に混和した培土を使用すると マット全体に生育むらが広く発生した。

$$
\text { キーワード }
$$

魚粉, 混和時期, 生育むら, 菜種油粕, プール育 苗

\section{引用文献}

江上宗信・本田義信・濱名健雄 - 佐々木園子 (2009)：水稲有機育苗に関する研究第 3 報有 機質肥料による追肥の効果, 東北農業研究 $62 ; 31-32$.

星川清親（1982）：イネの生育と技術, 育苗期, 稚 苗, 中苗, 成苗の特徵, 農業技術大系作物編 2 , イネ 1 , 農山漁村文化協会, 東京. pp, 109110.

菊地幹之・鈴木幸雄 $(2009)$ : 水稲有機栽培の育苗 に関する研究第 1 報自作培土の作成法，東北 農業研究 $62 ; 27-28$.

金和裕・金田吉弘・佐藤孝 (2007) : 有機質肥料の 層状施肥とプール育苗の組合せによる水稲有 機育苗技術，日作東北支部報 $50 ； 83-84$.

日本土䁃協会 (2012a)：第 1 部有機農業と標準栽 培技術指導書作成の方針, II 有機農産物の生 産害態と有機栽培の技術的課題， 2 有機栽培 における技術的課題, 日本土潩協会編, 有機 栽培技術の手引き (水稲・大豆編), 日本土壤 協会, 東京. $\mathrm{p}, 6$.

日本土㙵協会 $(2012 b)$ : 第 2 部水稲の有機栽培技 術, II 有機稲作の栽培技術解説, 2 育苗技術, 日本土壃協会編，有機栽培技術の手引き（水

稲・大豆編), 日本土潩協会, 東京, pp, 71-73. 岡山清司 (1987): 水稲の機械移植栽培における稚 苗育苗床土の適正酸度, 土肥誌 $58 ； 619-621$. 進藤勇人・原田久富美・小林ひとみ $(2006)$ : 水稲 有機 JAS 栽培に用いられている有機質資材 の窒素無機化特性と土壤還元への影響, 東北 農業研究 $59 ; 31-32$.

鈴木幸雄・菊地幹之 (2009) : 水稲有機栽培の育苗

に関する研究第 2 報ほかし肥料, ナタネ油粕 を利用した培土が苗生育に及ぼす影響，東北 農業研究 $62 ; 29-30$.

田淵恵・芝宏子・石橋英二 (2011)：鶏ふんを利用 した水稲の有機育苗法. 岡山県農業県報 2 ; $1-7$.

高橋行継・前原宏・阿部邑美 (1993) : 水稲のビニー ルプール箱育苗における平置き出芽法試験, 日作関東支報 $8 ； 25-26$.

高橋行継・佐藤泰史・前原宏・阿部邑美 (2004)： 群馬県の水稲普通期露地育苗における平置き 出芽法の適応, 日作紀 $73(3) ; 253-260$. 
高橋行継・吉田智彦 (2006) : 群馬県二毛作地帯に おける水稲育苗箱全量基肥栽培のプール育苗 法に関する検討，日作紀 75（2）；119-125.

浦野耕・高橋行継・平井英明 - 森島規仁 - 前田忠

信・星野幸一 (2011)：有機質肥料を用いた水 稲育苗の開発に関する研究，日作紀 81（1）; $45-54$.

熟尾養 (1982)：イネの生育と技術, 育苗期, 出芽 不良, 農業技術大系作物編 2 , イネ 1 , 農山漁 村文化協会, 東京, pp, 144-147.

山根忠昭（1986）: 有機質肥料, 市販有機質肥料,

植物質肥料, 菜種油粕, 山根忠昭, 農業技術 大系土壌肥料編 7-11, 農山漁村文化協会, 東 京. pp, 271-276.

米倉賢一・大下穣 (2000) : 水稲有機育苗法の確立

に関する研究第 4 報，日作紀 69（別 2)；8-9.

\section{Summary}

The present study aimed to develop a technique for raising middle rice seedlings under the pooled condition with organic fertilizer. We set up experimental plots in which rapeseed oil cake containing $1 \mathrm{~g}$ nitrogen and ground fish containing $1 \mathrm{~g}$ nitrogen were mixed with forest surface soil to prepare nursery soil. Plots were kept fallow for $0,1,2$, or 4 weeks. All plots appeared to have satisfactory growth conditions for middle rice seedlings, but irregular seedling growth were observed in the nursery boxes of the 4-week plots.

\section{Key Words}

ground fish, irregular growth of seedlings, mixing time, pool raising, rapeseed oil cake 